\title{
FREEZING DIFFERENCES: POLITICS, LAW, AND THE INVENTION OF CULTURAL DIVERSITY IN LATIN AMERICA
}

\section{DIFERENÇAS CONGELADAS: POLÍTICA, LEI, E A INVENÇÃO DA DIVERSIDADE CULTURAL NA AMÉRICA LATINA}

\begin{abstract}
The research analyzes the interference of power in society and in the transformation of individual life through the study of the mechanisms and social practices observed in Brazil from the nineteenth century, checking the legal system that led the institutions to change their daily implementing mechanisms disciplinary along with the implementation of public policies for the population along with the production of new truths that transformed the behavior of people with political and economic consequences of interfering with liberty. Therefore, the literature and the observational method were used for construction of the theoretical framework and development of the questions that are part of the research. Thus, it was noticed that the mechanisms of power act as a source of interference on the life of a population changing behaviors toward other more favorable habits to political and economic effects desired while appearing new social practices as liberty statements if opposing the power and therefore represent antagonism spaces to behaviors that are imposed, standardized and regulated, realizing the emergence of new truths.
\end{abstract}

Keywords: Power. Discipline. Biopower. Social Practices.
RESUMO: A pesquisa analisa a interferência do poder na sociedade e nas transformações da vida individual através do estudo dos seus mecanismos e das práticas sociais observadas no Brasil a partir do século XIX, verificando o sistema legal que levou as instituições a alterarem seu cotidiano implantando os mecanismos disciplinares junto com a aplicação de políticas públicas voltadas para a população juntamente com a produção de novas verdades que transformaram o comportamento das pessoas, com consequências políticas e econômicas interferindo na liberdade. Para tanto, a pesquisa bibliográfica e o método observacional foram utilizados para construção do arcabouço teórico e desenvolvimento dos questionamentos que fazem parte da pesquisa. Assim, percebeu-se que os mecanismos de poder atuam como fonte de interferência sobre a vida de uma população modificando comportamentos em direção a outros hábitos mais favoráveis aos efeitos políticos e econômicos desejados ao mesmo tempo em que aparecem novas práticas sociais como demonstrações de liberdade se opondo ao poder e, por isso, representam espaços de antagonismo a comportamentos que são impostos, normalizados e regulamentados, concretizando o aparecimento de novas verdades.

Palavras-chave: Poder. Disciplina. Biopoder. Práticas Sociais.

${ }^{1}$ Professor Titular da Freie Universität Berlin. Coordenador do Projeto desigualdes.net. E-mail: sergio.costa@fuberlin.de. 


\section{INTRODUCTION}

Since the 1980s, the legal and political tools for the protection of the cultural rights of minorities expanded considerably on the international realm, and are now par! of the catalog of fundamental guarantees assured by positive international law (BRUNKHORST, 2007; HABERMAS, 2005; MEYER, 2005).

This international expansion of cultural rights of minorities, while politically meritorious and necessary, is not free of problems. As emphasized by Will Kymlicka (2007), who is without a doubt the contemporary author who has made the most dedicated and detailed study of this process, the internationalization of minority rights is principally due to the adoption by multilateral agencies and international organizations of the liberal multiculturalist agenda. That is, even if there are important differences among the programs adopted by different international organizations, all of them adopted, in general, to the theoretical and political concepts defended by a specific approach in the broad discussion about culture and politics, that is, liberal multiculturalism (LM). As 1seek to demonstrate in this chapter, LM is based on an essentialist definition of culture that describes cultural identities as ancestral entities reproduced by processes that are endogenous to minorities and that are therefore prior to politics itself. Following this logic, the protection of the State is legitimated with the argument that it is necessary to create barriers among minority cultural groups and their surroundings so that the minority identities can be reproduced without being assimilated or marginalized by the dominant culture.

A vast body of theoretical work in the field of postcolonial studies, as well as empiric research in the field of cultural anthropology and the sociology of culture has shown that the effective processes of constitution of minority identities are neither prepolitical nor exclusively endogenous. Guided by a dynamic concept of culture, these 
studies make clear that minority cultures are articulated according to existing political opportunities and are constituted through relations with their surroundings.

Studies about the expansion of minority rights in Latin America have also confirmed the mobile and mutant character of the cultural identities of minorities. In most cases, the supposedly preexisting minorities who the cultural rights aim to protect, in reality are only constituted as a group because of new possibilities created for their legal recognition. That is, minorities do not predate law and politics, it is law and politics that constitute the minorities, leading them to reconstruct and reinvent their supposed common ancestra1 ties and their bonds of belonging in order to correspond to legal expectations and demands.

This argument will be developed in this chapter in four steps. First, I offer a summary of the theoretical debate in the realm of multiculturalism and of the principal theoretical criticisms that LM has suffered in the realm of postcolonial studies.

The second part presents a panorama of the impressive profusion of ethnic and cultural movements in Latin America, systematizing the arguments of recent studies that seek to explain their emergence.

The third part of the chapter is dedicated to the transformations observed in Brazil after the introduction, in the constitution of 1988, of protective guarantees for the "comunidades manescentes de quilombos" [quilombo remnants]- settlements originally established by groups who escaped from slavery, which lasted in Brazil until 1888.

Finally, in the conclusion, I seek to summarize the main criticisms of the international expansion of multiculturalism that can be identified in the theoretical debate and the cases studied. The objective is not to question the legitimacy of the legal guarantees and policies aimed to protect cultural minorities, but to outline a broader and realistic assessment of the impacts of these measures. 


\section{FROM MULTICULTURAL IDENTITIES TO NEW ARTICULATIONS OF DIFFERENCE}

Multicultural concepts in the field of political philosophy have been modified over time. Nevertheless, the contributions elaborated within the realm that Kymlicka (2007, p. 51) calls the "first wave of liberal multiculturalism," including his own work (KYMLICKA, 1989, 1995) as well as that of Taylor (1992), Raz (1994) and others produced in the late I 980s and early I 990s, continue to be highly influential ${ }^{2}$.

For the liberal multiculturalists, cultural differences do not have untouchable intrinsic value. Cultural traditions and repertoires are only valued because they provide important references for individual choices. That is, the maintenance of cultural diversity, for the liberals, only makes sense to the degree to which individuals, based on their own judgments and processes of reflection and formation of preferences, recognize themselves in the cultural repertoires, making use of them as a constitutive part of the exercise of their individual autonomy (RAZ, 1994; KYMLICKA, 1989; KYMLICKA, 1995). According to the liberal multiculturalists, two reasons justify why cultural belonging is crucial for the well-being of individuals. First, they show that cultural belonging provides individuals significant choices about how to conduct their lives, in the sense that familiarity with a culture indicates the limits of what it is reasonable to desire. The second argument is that cultural belonging has an important role in the identity of individuals, appearing as a primary space for identification, that is, belonging and cultural identity provide individuals a basis for self-identification. Consequently, the State has the function of protecting and stimulating cultural diversity, and, in some cases, recognizing the rights of minority cultural groups so that citizens can constitute their individual identity and have a cultural context that provides a foundation and meaning to their personal choices.

\footnotetext{
${ }^{2}$ In an article co-authored with Denílson Werle, during the most effervescent period of the theoretical debate around multiculturalisrn, we insisted on the distinction between LM and communitarian multiculturalism (COSTA; WERLE, 1997). I summarize in the following paragraph some of the arguments made in that work, avoiding, however, the reference to communitarian multiculturalisrn since it has almost no influence on the contemporary debate.
} 
Since the 1990s, LM has been suffering severe criticism from, among others, postcolonial studies (see, for example, BHABHA, 1994; 1995, 1996; GILROY, 2004, 2005, 2009; HALL, 1992, 1996, 1997; PIETERSE, 2007; HARITAWORN, 2010). Supported by a poststructuralist concept, these criticisms refuse the very idea of a cultural identity, prior to a political one. For this reason, in contrast to the homogenizing identity constructions that seek to prison and localize culture, they prefer to refer to the idea of difference, contextually articulated in the gaps in meaning between cultural borders. Difference here does not have the sense of biological or cultural inheritance, or of the reproduction of a symbolic belonging conferred by place of birth, residence, or by social or cultural insertion. Difference is constructed, in the very process of its manifestation, that is, it is not an entity or expression of an accun1tdated cultural stock; it is a flow of representations, articulated ad hoc, between the cracks of the all-encompassing externa! and essentialist identities. In these terms, even the remission to a supposed legitimacy bestowed by an "authentic" and "original" tradition must be treated as part of a performance of difference.

The representation of difference must not be hastily read as the reflection of pregiven ethnic or cultural traits set in the fixed tablet of tradition. The social articulation of difference, from the minority perspective, is a complex, ongoing negotiation that seeks to authorize cultural hybridities that emerge in moments of historical transformation. The "right" to signify from the periphery of authorized power and privilege does not depend on the persistence of tradition; it is resourced by the power of tradition to be reinscribed through the conditions of contingency and contradictoriness that attend upon the lives of those who are "in the minority" (BHABHA, 1994, p. 2).

The concept of difference formulated in the realm of postcolonial studies stems from the notion of différance, according to Derrida's definition (1972). By coining the neologism différance, as a play on the French word différence (difference), Derrida indicates the existence of a difference that is not translatable in the process of 
signification of signs, and cannot be organized into the identity polarities - 1/other, we/them, subject/object, wornen/man, black/white, signifier/signified. These binary distinctions and classifications constitute, following Derrida, the logocentric Western form of comprehending the world. These binarisms provide the bases for all modem structures of domination.

Authors such as Bhabha (1994) and Hall (1997) support themselves on the concept différance to escape the idea of a fixed, essential identity, whether it is ascribed or selfattributed. Poststructuralism serves here to deconstruct the polar discourses that oppose one $\mathrm{I}$ and another, one us and a them. This is true both for the colonial-imperialist discourse, as well as for the nationalist discourse and for the multiculturalist discourse, despite its good intentions. In all these cases, difference is celebrated as ho1nogeneous identity, irreducible sameness, given that a correspondence is established here between a socio-cultural insertion in a pre-discursive structure and a determined place of utterance in tl1e linguistic or political interplay. Instead of identity, the authors prefer to speak of identification, as a circumstantial position in webs of meaning (HALL, 1996; BHABHA, 1995, 1996).3 Following this line of argument, Pietcrse (2004, 2007) and Gilroy (2004) show that from this multiplicity of mobile and contingent identifications does not stem the cultural diversity described by multiculturalism, but a new multiculture. Multiculture refers to the depleting strength of cultural ascriptions to determine positions of power. Thus, in the realm of multiculture, the fact of being classified as British, black, immigrant, woman or indigenous becon1es irrelevant as a resource to define previous positions in asymmetrical power relations. For these authors, the coexistence desired between the different cultures is no longer that idealized by multicultural liberalism and guided by the constitution of protective barriers so that minority cultures can be reproduced (BOATCÃ;

\footnotetext{
${ }^{3}$ The key concept used by Hall (1996) to describe the position of the subject in the realm of a determined discursive formation is articulation, understood in a dual manner, that is, both the idea of expression as well as the tie between two ele1nents which may come together. The principle of contingent articulation can, according to Hall, be observed both in the formation of the individual subject as well as in the production of collective subjects.
} 
COSTA, 2010). The desired coexistence is guided by the ideal of conviviality, understood as "ordinary experiences of contact, cooperation and conflict across the supposedly impermeable boundaries of race, culture, identity and ethnicity" (GILROY, 2004, p. viii).

The concepts of identity, as well as of difference, developed in the realm of postcolonial studies challenge LM at a critical point, that is, they question the existence of ontological identities and the possibility for their political representation. As shown, for authors such as Bhabha and Hall, the moment of representation of difference is, simultaneously, the n1oment of its constn1ction, that is to say, of its articulation. In this reading, there is no social being prior to representation and which emerges publicly, at some time, to realize a latent destiny. Discourses and subject are simultaneously and mutually constituted. Therefore, when an ethnic minority or any other socio-cultural group appears in the public sphere as an identity unit, what is found there is not the public presentation of something that already exists in a latent manner, within the social being, but a circumstantial and contingent junction of the identity discourse as a group that comes to articulate its differences around that discourse. At another time, this sa1ne group can articulate other differences, based on other discourses.

In this sense, the institutionalized representation of cultural identities sought by multiculturalist policies signifies an effort to in prison and freeze something- differencewhich can only exist as something mobile, flexible, and variable.

\section{CONSTRUCTING DIVERSITY IN LATIN AMERICA}

In the past three decades, an extraordinary number of studies have been conducted that refer to different Latin American countries and that examine the region's recent explosion of cultural diversity. The concepts used to describe the phenomenon studied are equally varied. Some authors refer to the reinvention of ethnic identities (STAVENHAGEN, 2011), others detect the emergence of new forms of indigeneity (CANESSA, 2007; MCNEISH, 2008; ANDOLINA; RADCLIFFE; LAURIE, 2005) or of blackness (WADE, 1993; 
PINHO, 2005), while still others refer to processes of ethnicization of politics and politicization of ethnicity (BÜSCBGES; PFAF; CZARNECKA, 2007; RESTREPO, 2004).

The variety of concepts employed in the bibliography reflects theoretical differences among the authors, but also the diversity of groups in focus. Despite their divergences, these authors share a common attempt to explain how Latin American nations, 1nost of them established in consolidated nation-states in the early I 9th century, recently reveal a cultural diversity until now absent in the national discourses and in public space. That is, whether because of the simple use of violence, or through the ideology of malleable and inclusionary miscegenation, the Latin American States have historically displayed a great capacity to accommodate internal cultural differences, presenting over many decades great stability in the ties of symbolic belonging among their members. It thus involves understanding why, in the past three decades, Afro-descendants, indigenous peoples, descendants of immigrants, and other groups, who for a long time appeared to be assimilated within the national belonging in each one of the region's countries, emerge as cultural minorities requesting the right to be recognized based on cultural traits that supposedly separate and distinguish themselves from other members of the nation. In a very abbreviated form, the arguments found in the literature to explain the recent intensification of cultural diversity in Latin America can be systematized in four groups of interrelated factors ${ }^{4}$ :

a. The advance of the multicultural agenda on the international plane;

b. New political and legal opportunities that arose in the realm of processes of democratization and of institutionalization of multicultural rights and policies;

\footnotetext{
${ }^{4}$ A fifth and fundamental factor linked to the explosion of cultural diversity in conte1nporary LatinAn1erica is the new economic opportunities that have risen in the context of the global commodification of ethnic identities. This involves an increasingly expanding market for products that deserve, in some form, an ethnic label. A very illustrative case is studied by Patrícia Pinho (2008), African-A1nerican roots tourism to Bahia, Brazil. The author shows how the presence of tourists led to the formation of an "ethnic market," and to the recovery and invention of Afro-Brazilian cultural manifestations that were previously forgotten or simply did not exist. Since the present chapter focuses on interrelations between politics, law, and culture, I will not go into greater depth here into the discussion about the economic dimension of cultural diversity.
} 
c. Linkages between social inequality and cultural differences;

d. Emergence of social rnovements, NGOs, experts, and other brokers, capable of politically identifying and mobilizing target groups of the new cultural rights.

a) Since the 1980s, multiculturalism has been increasingly penetrating the agenda of international and multilateral agencies, giving shape to the process that Will Kymlicka (2007) called multicultural odysseys, that is:

the architects of the UN, and of post-war regional organizations, assumed that minority rights were not only unnecessary for the creation of a viable new international order, but indeed destabilizing of such an order. Today, however, it is widely asserted the accom1nodation of ethnic diversity is not only consistent with, but in fact a precondition for, the maintenance of a legitimate international order (KYMLICKA, 2007, p. 45).

In this context, international organizations such as the World Bank, the International Labor Organization (ILO), and bilateral cooperation agencies operating in Latin America seek to induce local governments to adopt measures to protect the cultural rights of indigenous peoples, Afro-descendents, and other groups considered to be culturally threatened. ${ }^{5}$ In the realm of international conventions and summit conferences, it is worth noting the impact for Latin American countries of International Labor Organization (ILO) Convention 169, the UN Conference against Racism held in Durban in 2001 and of the UN Declaration on the Rights of Indigenous Peoples of 2007 (BRIONES, 2005; FRENCH, 2009, p. 2).

ILO Convention 169 guarantees previously unprecedented rights to indigenous peoples and was ratified by nearly all of the Latin American countries. Over the years, the

\footnotetext{
${ }^{5}$ The fact that different international organizations followed the precepts of LM does not mean that fro1n a practical perspective they adopt the same procedures to guarantee the rights of minorities. J.P. Oliveira Filho (2000) studies the criteria used at the time by the World Bank to define who are indigenous peoples and finds that the Bank uses "indicators derived from an anachronist representation of the Indian as primitive [...]. [Thus, the] identification of a collectivity as 'indigenous' becomes a question of degree, of greater proximity or distancing from the stereotype of primitivty" (OLIVEIRA FILHO, 2000, p. 130). For th1s author, the Bank would resolve many of its difficulties in classification if it would adopt the principle of self-identification established in International Labor Organization Convention 169.
} 
guarantees established by the convention were being incorporated to the constitutions and public policies of different countries in the region, offering new opportunities for recogniti9n for indigenous and other groups treated as "traditional or orginary populations" (VAN COTT, 2000; BRIONES; KRADOLFOR, 2008, p. 14). The Durban Conference, in turn, stin1ulated an important set of 1neasures to combat racism and discrimination in Latin America. The adoption of affirmative action programs in countries such as Colo1nbia and Brazil and the creation of a secretarial position with ministerial status to promote racial equality in Brazil are direct results of the conference's resolutions (COSTA, 2011a; GÓNGORA-MERA, 2012).

The Declaration of the Rights of Indigenous People of 2007, in turn, has an inescapable symbolical meaning given that the representatives of the indigenous peoples had a decisive participation in its drafting:

this Declaration has the distinction of being the only Declaration in the UN which was drafted with the rights-holders then1selves, the Indigenous Peoples. 1 hail the independent experts and representatives of States and NGOs who contributed actively to this process. This magnificent endeavour which brought you to sit together with us, Indigenous Peoples, to listen to our cries and struggles and to hammer out words which will respond to these is unprecedented (TAULI-CORPUZ, 2007, p. 6).

Among the regional organizations of the American continent, the Inter-American Commission on Human Rights should be highlighted. In the realm of the Inter-American Court on Human Rights and its internal departments such as the Rapporteurship on the Rights of Indigenous Peoples, created in 1990, and the Rapporteurship on the Rights of Afro-Descendants and against Racial Discrimination, created in 2005, the Comn1ission sought to guarantee the execution and implementation of the international agreements and conventions in the different member countries (OLMOS, 2010; COSTA; GONÇALVES, 2011).

b) At the time in which this set of conventions, resolutions, and instruments was created internationally, most of the Latin American countries were internally experiencing 
a process of redemocratization after decades of domination of military dictatorships, as in the cases of Argentina, Brazil, Chile, and many others, or of a single party system, as in the case of Mexico. The new democratically elected governments, in most cases, adopted the guarantees and rights established internationally, thus creating, in the realm of domestic policy, benefits until then unprecedented for population groups who could be recognized as indigenous or remnants of ancestral or traditional populations. They involve, for example, property demarcation and the concession of deeds, special public health programs, bilingual education, and so on.

The redemocratization period also coincides with the adoption, in most Latin American countries, of structural readjustment policies according to the neoliberal agenda. In this context, marked by considerable limits on State spending, programs to promote cultural diversity constitute an exception, to the degree to which they offer access to public resources not available for other social policies. It is this structure of political opportunities that allows population groups previously identified as poor peasants or urban workers to rearticulate themselves politically, and emphasize their ethnicity in the public realm (BRIONES, 2005; RESTREPO, 2004; DÁVALOS, 2004).

This type of ethno-political reidentification is well described by Andrew Canessa (2007) for the case of an indigenous group in Bolivia. His description is paradigmatic of processes observed by many other authors in relation to the indigenous, Afrodescendants, and other "traditional or ancestral populations" in practically all Latin American countries: ${ }^{6}$

\footnotetext{
${ }^{6}$ In addition to well-studied and well-known cases like that of Afro-descendents in Colombia (WADE, 1993; RESTREPO, 2004) and Brazil (WADE, 2005; SANSONE, 2003; ALMEIDA, 2000) or indigenous peoples in the Andean countries (DÁVALOS, 2004; WALSH, 2005, 2009), it is worth 1nentioning the less well-known example of French Guiana, as described by Brightman (2008). Brightman (2008) perceives an apparent contradiction between t4e dynamic character of relations among the indigenous and the ontological and ancestral way that they represent themselves in political space. He affirms that this paradox is explained by the fact that indigenous peoples turn to a "strategic ethnicity [...] in their political interventions in a political arena whose terms are dictated by Western tradition" (BRIGHTMAN, 2008, p. 27).
} 
In a recent book, Bruce Mille1. (2003) explores state policies which render indigenous people 'invisible' by refusing to recognize them as such. What I explore below is an opposite example: one of people who are recognized by the state as being indigenous but who do not then1selves norn1ally identify as such. At root is the issue of the state deciding who is and who is not indigenous and of indigeneity being conceived as a particular relationship with the state, rather than a syste $1 \mathrm{n}$ of meanings generated from within a particular culture. (CANESSA, 2007, p. 210)

c) The possibility for ethnic or cultural reidentification is not arbitrary or fortuitous. It is due to the effectively existing link between social inequalities, understood in the broad sense as econo1nic, political, and legal asym1netries, and ascriptions of an ethnic, racial, or cultural nature. What is being affirmed here, obviously, is not that all the Latin American poor or those denied access to political or social rights are Afro-descendants or indigenous. In reality, it involves distinct and more complementary types of inequalities. In order to address the articulation between social inequality and cultural identities, Stewart and her research group (STEWART, 2010; STEWART; BROWN; MANCINI, 2005) refer to vertical inequalities to characterize assymetries between individuals, and to horizontal inequalities to qualify inequalities that affect population groups as a whole. ${ }^{7}$ Accordingly, the common experiences of discrimination can cause the potential belonging to the discriminated group to be reinforced:

To some extent, then, group boundaries become endogenous to group inequality. If people suffer discrimination (i.e. experience horizontal inequality) they may then feel cultural identity more strongly, particularly if others categorise thein into groups for the express purpose of exercising discrimination (thereby creating or enforcing HIs [horizontal inequalities]) (STEWART; BROWN; MANCINI, 2005, p. 9).

d) The identification and translation of cultural rights and guarantees that have arisen on international and national realms imply for their potential beneficiaries a

\footnotetext{
${ }^{7}$ The horizontal inequalities are notable in all countries of Latin America that collect population data according to categories of ethnic or racial belonging. In Brazil, for example, 21,7 per cent of whites, but 44,8 per cent of Afrodescendents are poor: In Ecuador, 58,5 per cent of Afro-descendents and 39,6 per cent of whites and mestizos are poor (cf. ANTON et al., 2009). In Peru, 55,4 per cent of the indigenous, 28 per cent of the rnestizos and 9 per cent of the whites are considered poor (cf. THORP; PAREDES, 2010; see also COSTA, 2011b).
} 
complex process of interpretation and political agency. Here, several intermediaries enter the scene. They are capable of dialoging and communicating with the beneficiaries and, at the same time, they dominate the language and codes of different specialized systems involved in demanding new rights and their materialization. The bibliography about the issue is vast and refers to actors of a highly varied nature, from individual experts and collective actors such as social move1ncnt organizations to institutions such as congregations and churches. The analysis of Martí i Puig (2010) elucidates the role of these brokers in the emergence of indigenous movements in Latin America. The author distinguishes a1nong actors "from below and outside" and actors "from above". The first actors are represented by the Catholic Church and by anthropologists who, since the I 970s, have contributed to the political mobilization of the indigenous and to the intermediation of their contacts with the State. The actors from above correspond to activists in advocacy networks:

Activists from different parts of the world who were interested in development, human rights, and ecology and e1nbraced the cause of the self-detern1ination of indigenous peoples sprang from these networks and had a significant impact on the configuration of the indigenous movement (MARTÍ IPUIG, 2010, p. 79).

In other cases, such as the articulation of the move1nents of Afro-descendants, other mediators, such as NGOs, sociologists, or black intellectuals, have assumed the role of politically decodifying the research about racial discrimination and social inequality, transforming social indicators into arguments for political mobilization.

Below, I briefly analyze the implementation of a policy to protect the Maroon population in Brazil to show how the different dimensions of the construction of cultural diversity in Latin America, as described here, take form in a specific case.

\section{LAW AND LEGENDS: A BRAZILIAN EXPERIENCE}

The Brazilian Constitution of 1988 was promulgated amid the political euphoria triggered by democratization, after 21 years of military dictatorship (1964--1985). The 
constitutional text is, for this reason, extremely progressive and open to the extension of political, social, and cultural rights of different population groups. Among the many guarantees established, the constitution defines in article 68 of the Temporary Constitutional Provisions Act] that: "Final ownership shall be recognized for the remaining me1nbers of the ancient runaway slave comn1tmities [quilombos] who are occupying their lil1ds il1d the state shall grant them the respective title deeds" (BRAZIL, 2010, p. 184). ${ }^{8}$

According to Arruti's (2000, p. 130) detailed reconstruction, the category quilombo used in the constitutional text is:

subservient to repressive legislation of colonial origin that to be effective made itself generic and exterior to those it addresses, relates to a historic social formation that in principle disappeared with slavery and which was characterized exactly because of a quest to be invisible before the State.

Thus, at the time of the enactment of the Brazilian Constitution in 1988, there were no groups demanding to be recognized as quilombo remnants. There was only a very 1nc1p1ent n1ovement among rural black communities in Pará and Maranhão States. According to Arruti, two parallel movements explain the inclusion of article 68 in the Constitution of 1988. On one hand, rural workers' movements and government agencies identified the existence of different forms of rural land possession without a clear legal statute and which should be regularized. This included lands acquired or occupied by former slaves and on which their descendants continued to live. Or the other hand, the quilombos occupied (and continue to occupy) an outstanding place in the political repertoire of the black movement in Brazil, to the degree to which they symbolize resistance to exploitation and slavery. It is therefore the conjunction between the diffuse need to regularize land ownership and the influence of the black movement that explains the inclusion of the reference to the "remanescentes de quilombos" in the constitution of 1988.

\footnotetext{
${ }^{8}$ Original text: "Art, 68. Aos remanescentes das comunidades dos quilombos que estejam ocupando suas terras é reconhecida a propriedade definitiva, devendo o Estado emitir-lhes os títulos respectivos" (BRAZIL, 1988).
} 
The constitutional article stimulated an extensive series of political mobilizations and an identity reconfiguration of those rural communities that had an expressive black population. Many of them, in part assisted by anthropologists, religious agents, and activists from the quilon1bo remnant movement that was being formed, began to see article 68 as an opportunity to resolve land ownership conflicts in which they were involved.

In 2003 a presidential decree established a definitive process for the implementation of regularization of lands of the quilombo remnants. According to the decree, the criteria for recognition of the communities is established by self- identification, that is, it is the beneficiaries themselves who identify themselves as quilombo remnants. ${ }^{9}$ The decree also defines that the land deeds to the quilombos not be placed in the name of individuais, but in that of the association that represents the community in question. In the decree, as Arruti (2009, p. 85) observed, the land assumes the connotation of a territory:

it includes not only the land directly occupied at the specific time the deed is issued, but all of the spaces that are part of its uses, customs and traditions and/or that have the environmental resources needed for their maintenance and to the historic reminiscenes that allow perpetuating the memory.

The Brazil Quilombo program (Programa Brasil Quilombola) was created in 2004 to organize activities in 23 ministries and federal agencies related to the quilombo remnant communities (SEPPIR, 2005). At the end of 2011 Brazil had 3,524 quilombo communities that are potential targets of the program's activities, which have "as their main objectives the guarantee of access to land; healthcare and education actions; construction of residences, electrification; environmental recuperat1on; incentives to local development;

\footnotetext{
${ }^{9}$ The definition of the criteria for self-recognition as a substitution for an anthropological report to define if a group is a quilombo remnant or not represent an important step in the process that French $(2009$, p. 6) called "postlegislative negotiation" of the law. The criteria for self-recognition is in keeping with ILO convention 169 mentioned above and was determined after pressure from the Brazilian Anthropological Association, which in 1995 created a special working group called "Terra de Quilombo" [Quilombo Land] which insisted on the need to "incorporate the perspective of the social groups that sought, in their actions, the application of the law attributed by the Federal Constitution (O'DWYER, 2005, p. 94, see also O'DWYER, 2011).
} 
complete provision of social programs to the quilombo families, such as the Family Grant program; and measures for preservation and promotion of the quilombos' cultural manifestations" (SEPPIR, 2005, emphasis added).

Anthropologists José Maurício Arruti (2000) and Jan French Hoffman (2009) study, from different perspectives, the regularization of the quilombo and in the locality of Mocambo, in Sergipe State in Brazil. The case is highly instructive to demonstrate how the constitutional change introduced by article 68 provokes, at the local level the construction of an ethnic group.

The history of the community of Mocambo is inseparable from the trajectory of the indigenous community of Xocó, its neighbor. Both groups had lived, for many decades, in an instable situation of land ownership, and were permanently threatened with expulsion from the lands that they occupy. In the 1940s and 1950s they came to jointly participate in the peasant movements in the region. ${ }^{10}$ Many families were also constituted by marriages between members of the two communities, bluring ethnic and cultural borders between the two groups. Since the 1970s and 1980s, the indigenous Xocó people, supported by the Missionary Indigenist Council, an entity linked to the Catholic Church, more clearly assumed its indigenous identity, which allowed them, through the prerogatives offered by indigenous law, to regularize the collective property of the lands that they occupied (FRENCH 2009, p. 49).

Meanwhile, the situation of the inhabitants of Mocambo continued to be precarious. Then, pastoral agents working in the Mocambo community, aware of the first successes in other regions of the regularization of lands of quilombo remnants based on

\footnotetext{
${ }^{10}$ In fact, the identities assumed by the rnembers of the two communities over the years varied considerably: "[...] the people in both communities have been identified and have selfidentified over the years in a variety of ways: camponeses (peasants), trabalhadores rurais (rural workers), caboclos (1nixed race with indigenous ancestry), negros (blacks), católicos (Catholics), pobres (poor people), sertanejos (frorn the interior), sergipanos (residents of Sergipe), nordestinos (Northeasterners), meeiros (sharecroppers), posseiros (squatters), índios (Indians), remanescentes (descendants of fugitive slaves), and quilornbolas, sometimes simultaneously and other times sequentially, as the state, its agents, the people thernselves, and their advisers took up or ignored one or another of these sociolegal identities" (2009, p. 13, italics in the original).
} 
the constitutional prerrogative introduced in 1988, sought to convince the Mocambo residents of the advantages of this legal alternative. The option, however, was rejected in principle by the co1nmunity, given that:

the idea of an identification as "quilombo remnants" is not part of the type of representation that the fa1nilies of Mocambo had or would like to produce about themselves. The resistance of those families to the suggestion that they consider themselves as "quilombolas" was so great that they carne to discuss the possibility of changing the name of the community, from "Mocainbo" [a synonym for quilombo] to Mundo Novo [New World] (ARRUTI, 2000, p. 110) .

The legal advantages, however, were persuasive, leading the Mocambo residents, after many discussions and political disputes, to publically accept themselves as a remnant quilombo community. This political reconversion is accompanied by the intensified presence of outside interlocutors and the introduction of new cultural practices. Anthropologists, activists from the movement of quilombo remnants and agents of the state involved in granting land deeds began to frequent Mocambo. Internally, the memory of resistance to slavery and racial oppression was (re)discovered through the selection and resignification of the dances and songs traditionally sung in the community, as described by French $(2009$, p. 149). A theatrical play presented by adolescents in the community also had an important role and was presented each year during the commemoration of the recognition of the community as a quilo1nbo re1nnant, a process concluded in 2000. In recent years, the play that tells the story of a local family has been changing and transformed into "the founding narrative of those in Mocambo who ca1ne to identify the1nselves as black people descended from fugitive slaves" (FRENCH, 2009, p. 154).

The process of introducing laws to recognize the territories of the quilon 1 bo remnants in Brazil, both when observed from the perspective of political negotiations for their imple1nentation, as well as when reconstructed from their local impacts in Mocambo, offers fertile material for studying the relationships between politics, law, and 
cultural diversity. Thus, the trajectory of the quilombo legislation and the case of the Mocambo community briefly reconstructed in this section, allow perceiving the different dimensions involved in the recent invention of cultural diversity in Latin America, as described in the previous section.

First the Brazilian laws were introduced at the time of the strong expansion of multiculturalism on the international agenda and were reformulated in 2003, adapting to the criteria ILO Convention 169. Transnational references can also be noticed in the political and cultural repertoire that guides the formulation of the law and its application even in the local context. There are numerous allusions to the African diaspora, the global history of modem slavery and transnational solidarity and resistance to racial oppression, both in the political repertories of the social movements involved in the process and in the vocabulary used by the Brazilian government programs aimed at the population of quilombo remnants.

The role of the new cultural rights in inducing the ethnic reidentification of the populations involved is also previously identifiable. Groups that had previously identified themselves as rural workers or squatters rediscovered themselves as quilombo remnants. The connections between social inequality and cultural difference are just as obvious. It is the situation of denial of the right to land and the disadvantageous position in the social structure that has finally motivated Brazilian citizens to request protection from the State as quilombo remnants. The role of the cultural and political mediators is evident. Nationally, the black movement, political activists, the Brazilian Anthropology Association, and State agencies have contributed to establishing the form and meaning that the legislation has acquired over time. Locally, church workers, individual anthropologists, political activists, and State agents have allowed the law to be interpreted and translated for the potential target group. 


\section{CONCLUDING REMARKS}

LM established itself as a theoretical approach and guiding reference for public policies since the late 1980s based on political and theoretical debates about experiences with cultural minorities observed in Canada, the United States, and a few countries of Western Europe. Since then, LM has penetrated with extraordinary strength the agenda of international organizations and cooperation agencies.

The different versions of LM have as a common core the conviction that the preservation of the variety of existing cultural repertoires is essential to guaranteeing freedom and a sense of individual choices. According to this logic, the legitimacy of the cultural rights of minorities is not based on the intrinsic value of the different cultures, but on the importance of these rights for guaranteeing the complete exercise of individual autonomy.

As I have shown, LM presents a set of problematic theoretical and political assumptions. In the first place, it is based on an essentialist notion of cultural identity. It defines the cultural identity of individuals and groups as a reflection of a stock of representations, values, and patterns of behaviour that exist prior to social relations. Critics of LM convincingly demonstrate that cultural identifications are always temporary and do not atavistically repeat supposedly learned repertories. To the contrary, cultural identifications, as contingent articulations of differences, express a selective recourse to the multiplicity of existing cultural forms, according to the possibilities and constraints determined by each specific interaction.

A second limitation of LM is its myopia to the connections between cultural identifications and social inequalities. Multiculturalism refers to minority cultures as carriers of cultural repertories distinct from the majority culture, without considering that cultural differences do not have an isolated existence, exterior or prior to politics and social and power relations. Cultural differences are always enunciated from a particular 
position of a group or individual in a local, national, and global structure of social and political inequalities.

The theoretical and political limitations of LM, already present in the context of their rise in a few countries of the Northern Hemisphere, become obvious as international organizations globalize LM.

As the recent profusion of cultural diversity in Latin America reveals, measures destined to protect cultural minorities implemented in the region do not generate the desired cultural preservation of the cultural minorities, nor do they expand individual autonomy. In solne cases, the measures implemented produce a profound transformation of the minority cultures, given that the groups that they want to protect are led to relate with a large variety of external agents, to learn new vocabularies and strategies, and to pass through unknown forums and spheres. To supposedly guarantee the right to remain as they are, these groups find themselves required to perform a multiplicity of new political roles completely foreign to those traditions that LM wants to preserve. In other cases, the measures implemented simply create cultural minorities that did not previously exist. This occurs, as illustrated by the case of the quilombo remnants in Brazil, when cultural rights provide the only route possible for conquering social benefits such as medical assistance, public education, or regularization of land ownership.

The criticisms presented here of really existing LM should not be confused with a condemnation of the objective to protect cultural minorities. They involve, however, "deprovincializing" LM, uprooting it from its Western origin. From a theoretical perspective, to deprovincialize multiculturalism implies broadening its philosophical and empiric references, enriching it through the incorporation of a broader discussion of the relationships between politics, law, and culture accumulated in different regions of the world, in some cases for more than a century and not only for three decades.

From a political perspective, globalization of cultural rights cannot be separated from the debate about social inequalities and asymmetries of power. That is, to truly 
represent an expansion of autonomy and of individual liberties, cultural rigbts cannot be disassociated from a profound extension of social rights. If they are, cultural rights become a substitute-and an errouneous one-for other basic rights.

\section{REFERENCES}

ALMEIDA, M. Um mar da cor da terra. Raça, cultura e política da identidade. Oeiras: Celta, 2000.

ANDOLINA, R., RADCLIFFE, S.;LAURIE, N. Gobernalidad e identidad: Indigeneidades transnacionales en Bolivia. In: DÁVALOS, P. (Org.). Pueblos indígenas, estado y democracia. Buenos Aires: Clacso, 2005, p. 133-79.

ARRUTI, J.M. Direitos étnicos no Brasil e na Colômbia: notas comparativas sobre hibridização, segmentação e mobilização política de índios e negros. Horizontes antropológicos, v. 6, n. 14, p. 93-123, 2000.

ARRUTI, J.M. Políticas públicas para quilombos. Terra, saúde e educação. In: DE PAULA, Marilene; HERINGER, R. (Org.). Caminhos convergentes. Estado e sociedade na superação das desigualdades raciais no Brasil. Rio de Janeiro: Heinrich Bõll Stiftung, ActionAid, p. 75110, 2009.

BHABHA, H. The location of culture. London, New York: Routledge, 1994.

BHABHA, H. Cultural diversity and cultural differences. In: ASHCROFT, B.; GRIFFITHS, G.; HELEN, H. (org.). The postcolonial studies reader. London \& New York: Routledge, 1995, p. 206-69.

BHABHA, H. Culture's in-between. In: HALL, S.; GAY, P. du (Org.). Questions of cultural identity. London: Sage, 1996, p. 53-60.

BOATCÃ, M.; COSTA, S. Postcolonial sociology: A research agenda. In: RODRÍGUEZ, E.; BOATCÃ, M.; COSTA, S. (Org.). Decolonizing european sociology. Transdisciplinary Approaches. Surrey: Ashgate, 2010, p. 13-32.

BRAZIL. Constituição da República Federativa de 1988 [Online]. Available at: http://www.planalto.gov. br/ccivil_03/constituicao/Constituicao.htm. Aaccessed: 2 January 2012.

BRAZIL. Constitution of the Federative Republic of Brazil. Brasília: Câmara dos Deputados, 2010. 
BRIGHTMAN, M. Strategic ethnicity on the global stage: Identity and property. The global indigenous peoples' movement, from the Central Guianas to the United Nations. In: Bulletin der schweizerische amerikanisten-gesellschaft, 70, p. 21-9, 2008.

BRIONCS, C. Formaciones de alteridad: Contextos globales, procesos nacionales y provinciales. In: BRIONCS, C. (Org.). Cartografias argentinas: políticas indigenistas y formaciones provinciales de alteridad. Buenos Aires: Geaprona, 2005, p. 11-44.

BRIONES, C.; KRADOLFER, S. Dilemas y paradojas de la internacionalización de los movimientos indígenas en América Latina: una introducción. Bulletin der schweizerische amerikanisten-geselschaft, 70, 2008, p. 11-19.

BRUNKHORST, H. Die Legitimationskrise der Weltgesellschaft Global Rule of Law, Global Constitutionalism und Weltstaatlicbkeit. In: MATTHIAS, A.; STICHWEH, R. (Org.). Weltstaat und weltstaatlichkeit. Wiesbaden: VS Verlag, 2007, p. 63-108.

BÜSCHGES, C.; PFAFF-CZARNECKA, J. (Eds). Die ethnisierung des politischen: Identitdtspolitiken in Lateinamerika, Asien und den USA. Frankfurt: Campus, 2007.

CANESSA, A. Who is indigenous? Self-identification, indigeneity, and claims to justice in contemporary Bolivia. Urban Anthropology, v. 36, n. 3, p. 14-48, 2007.

COSTA, S. Au-delà du métissage. Antiracisme et diversité culturelle sous les deux gouvernements Lula. Problemes d'Amérique Latine, v. 78, 91-112, 2010.

COSTA, S. Perspectivas y políticas sobre racismo y afro-descendencia en América Latina y el Caribe. In: M. Hopenhayn and A. Soja (org.) Sentido de pertenencia en sociedades fragmentadas: América Latina en una perspectiva global. Buenos Aires, Santiago: Sigla XXI, CEPAL, 2011a , p. 173-88.

COSTA, S. Researching entangled inequalities in Latin America: The role of historical, social, and transregional interdependencies. Working Paper Series 9. Berlin: DesiguALdades.net. [Online]. Available at: http://www. desiguALdades.net [accessed: 10 December 2011b.

COSTA, S. ; GONÇALVES, G.. Human rights as collective entitlement? Afro-descendants. In: Latin America and the Caribbean. Zeitschrifl fur Menschenrechte, 2011, p. 52-71.

COSTA, S.;WERLE, D.. Reconhecer as diferenças: Liberais, comunitaristas e as relações raciais no Brasil. Novos Estudos, Cebrap, v. 49, 1997, p. 159-80.

DÁVALOS, P. Movimiento indígena, democracia, Estado y plurinacionalidad en Ecuador. Revista Venezo/ana de Economia y Cíencias Sociales, v. 10, n. 1, p. 175-202, 2004.

DERRIDA, J. Die schrift und die differenz. Frankfurt: Suhrkamp, 1972.

FRENCH, J.H. Legalizing identities. Becoming black or indian in Brazil's Northeast. Chapel Hill: University of North Carolina Press, 2009. 
GILROY, P. After empire. melancholia or convivial cultures. London, New York: Routledge, 2004.

GILROY, P. Melancholia or conviviality: The politics of belonging in Britain Soundings. A Journal of Politics and Culture, 29, 35-47, 2005.

GILROY, P. Darker than blue: On the Moral Economies of Black Atlantic Cultures. Cambridge: Harvard University Press, 2009.

GÓNGORA-MERA, M.E. Law \& race beyond the state. Rethinking race-based inequalities in Latin America from a legal historical perspective. Working Paper. Berlin: DesiguALdades.net, 2012.

HABERMAS, J. Zwischen natruralismus und religion. Philosophische aujsdtze. Frankfurt: Suhrkamp, 2005.

HALL, S. The question of cultural identity. In: HALL, S., HELD, D.; MCGREW, T. (Org.). Modernity and its futures. Cambridge: Polity Press, 1992, p. 273-325.

HALL, S. On postmodernism and articulation, interview edited by Lawrence Grossberg, In: MORLEY, D.; KUAN-HSING, Ch. (Org.). Stuart Hall. Critical dialogues in cultural studies. London, New York: Routledge, 1996, p. 131--50.

HALL, S. The work of representation. In: HALL, S. (Org.) Representation: cultural representations and signifying practices. London: Sage, Open University, 1997, p.13-74.

HARITAWORN, J. Wounded subjects: Sexual exceptionalism and the moral panic on "migrant homophobia" in Germany. In: RODRÍGUEZ, E.; BOATCÃ, M.; COSTA, S. (Org.). Decolonizing european sociology. Transdisciplinary approaches. Surrey: Ashgate, 2010, p. 135-52.

KYMLICKA, W. Liberalism, community and culture. New York: Oxford University Press, 1989. KYMLICKA, W. Multicultural citizenship: A Liberal Theory of Minority Rights. Oxford: Oxford University Press, 1995.

KYMLICKA, W. Multicultural odysseys. Oxford: Oxford University Press, 2007.

MARTÍ-I-PUIG, S. The emergence of indigenous movements in Latin America and their impact on the Latin American political scene. Latin American Perspectives, v. 37, n., 6, p. 7492, 2010.

MCNEISH, J.A. Beyond the permitted Indian Bolivia and Guatemala in an era of neoliberal developmentalism. Latin American and Caribbean Ethnic Studies, v. 3, n. 1, p. 33-59, 2008.

MEYER, J. Weltkultur. Wie die westlichen prinzipien die welt durchdringen. Frankfurt: Suhrkamp, 2008. 
O'DWYER, E.C. Os quilombos e as fronteiras da antropologia. Antropolitica, v. 19, p. 91-111, 2005.

O'DWYER, E.C. Etnicidade e direitos territoriais no Brasil contemporâneo. Iberoamericana, $v$. 42, p. 111-25, 2011.

OLIVEIRA FILHO, J.P. Cidadania e globalização: Povos indígenas e agências multilaterais. Horizontes antropológicos, v. 14, p. 125-41, 2000.

OLMOS GIUPPONI, B. La protección de las comunidades afro-descendientes en el Sistema Interamericano: Reflexiones a la luz dei caso de las comunidades Jiguamiadó y de Curbaradó. Revista Eletrónica Iberoamerica, v. 4, n. 2, p. 61-97, 2008.

PIETERSE, J.N. Globalization and culture. Lanham: Rowman \& Littlefield, 2004.

PIETERSE, J.N. Ethnicities and global multiculture: Pants for an Octopus, Lanham: Rowman \& Littlefield, 2007.

PINHO, P.S. Descentrando os Estados Unidos nos estudos sobre negritude no Brasil. Revista Brasileira de Ciências Sociais, v. 59, p. 37-50, 2005.

PIUHO, P.S. African-American roots tourism in Brazil. Latin American Perspectives, v. 160, p. 70-86, 2008.

RAZ, J. Multiculturalism: A liberal perspective. Dissent, v. 41, n. 1, p. 67-79, 1994.

RESTREPO, E.. Ethnicization of blackness. In: Colombia. Toward de-racializing theoretical and political imagination. Cultural Studies, v. 18, n. 5, p. 698-715, 2004.

SANSONE, L. Blackness without ethnicity: Constructing Race in Brazil. Basingstoke: Palgrave Macmillan, 2003.

SEPPIR. Programa Brasil Quilombola. Brasília: Secretaria Especial de Promoção de Políticas de Igualdade Racial [Online]. Available at: http://www. seppir.gov.br/acoes/pbq. Accessed: 2 January 2012. Publish, 2005.

STAVENHAGEN, R. La identidad indígena en América Latina. In: M. Hopenhayn and A. Sojo (org.). Sentido de pertenencia en sociedades fragmentadas: América Latina en una perspectiva global. Buenos Aires, Santiago: Sigla XXI, CEPAL, 2005, p. 227-243.

STEWART, F. Por qué persisten las desigualdades de grupo? Las trampas de la desigualdad horizontal. In: JIMÉNEZ (Org.) Teoría económica y desigualdad social. Exclusión, desigualdad y democracia. Homenaje a Adolfo Figueroa. Lima: Pondo Editorial de la PUC-Perú, p. 269298, 2010.

STEWART, F., BROWN, G.; MANCINI, L. Why Horizontal Inequalities Matter: Some Implications for Measurement [Online]. Working Paper 19. Oxford: Crise, University of Oxford. Available at: http:I/www.crise.ox.ac.uk/pubs/ worldngpaperl 9.pdf. Accessed: 10 December 2005. 
TAULI-CORPUZ, V. From the statement of Victoria Tauli-Corpuz, Chairperson of the UN Permanent Forum on Indigenous Issues. In: (Org.). United Nations: declaration on the rights of indigenous peoples [Online]. New York: United Nations, v. 1, n. 5. Available at: http://www.un.org/esa/socdev/unpfii/documents/Declaration_ip_vtc.doc. Accessed: 2 February 2012.

TAYLOR, C. Multiculturalism and the politics of recognition: An Essay. Princeton: Princeton University Press, 2007.

THORP, R.; PAREDES, M. Ethnicity and the persistente of inequality. The Case o.f Peru. Honndmills: Palgrave Macmillan, 2010.

VAN COTT, D.L. The friendly liquidation of the past: The Politics of Diversity in Latin America. Pittsburgh: University of Pittsburgh Press, 2000.

WADE, P. Blackness and race mixture: The Dynamics of racial identity in Colombia. Baltimore: Johns Hopkins University Press, 1993.

WADE, P. Rethinking mestizaje: ideology and lived experience. Journal of Latin American Studies, v. 37, n. 2, 2007, p. 239-57.

WALSH, C. 2005. (De)Construir la interculturalidad. Consideraciones críticas desde la política, la colonialidad y los movimientos indígenas y negros en Ecuador. In: FULLER, N. (Org.) Interculturalidad y política. Desafios y posibilidades. Lima: Red para el Desarrollo de las Ciencias Sociales en Perú, 2005, p. 115-42.

WALSH, C. Interculturalidad, estado, sociedad: luchas (de) coloniales de nuestra época. Quito: Universidad Andina Simon Bolívar, 2009.

COSTA, Sérgio. Freezing Differences: Politics, Law, and

the Invention of Cultural Diversity in Latin America. RBSD

- Revista Brasileira de Sociologia do Direito, v. 3, n. 2, p.

8-32, mai./ago. 2016.

Recebido em: 18/04/2016

Autor convidado 